\title{
Mapping the Literature on Financial Behavior: a Bibliometric Analysis Using the VOSviewer Program
}

\author{
MAKSYM DUBYNA \\ Department of Finance, Banking and Insurance, \\ Chernihiv Polytechnic National University, \\ Chernihiv, 14039, UKRAINE \\ OLHA POPELO \\ Department of Management and Civil Service, \\ Chernihiv Polytechnic National University, \\ Chernihiv, 14039, UKRAINE \\ NATALIIA KHOLIAVKO \\ Department of Finance, Banking and Insurance, \\ Chernihiv Polytechnic National University, \\ Chernihiv, 14039, UKRAINE \\ ARTUR ZHAVORONOK \\ Department of Public, Corporate Finances and Financial Mediation, \\ Yuriy Fedkovych Chernivtsi National University, \\ Chernivtsi, 58029, UKRAINE \\ MAIIA FEDYSHYN \\ Department of Public, Corporate Finances and Financial Mediation, \\ Yuriy Fedkovych Chernivtsi National University, \\ Chernivtsi, 58029, UKRAINE \\ INNA YAKUSHKO \\ Department of Management, \\ IHE “Academician Yuriy Bugay International Scientific and Technical University”, \\ Kyiv, 02000, UKRAINE
}

\begin{abstract}
The objective of the article is to study the current state of researches of financial behaviour. The article is conceptual and based on the use of the methodology of the bibliometric analysis. The analysis is based on data retrieved from functionalities of the Scopus and Web of Science platforms. The VOSviewer program is used for network visualization of keywords in scientific publications. Key findings are the number of publications directly study the nature and features of the financial behavior formation of various economic agents is insignificant, but is constantly growing. An important role in this process is played by digitalization processes of financial services, which have an important impact on the models transformation of both financial behavior of economic agents, and changes in the model of the financial services provision to customers by financial institutions.
\end{abstract}

Key-Words: - Financial Behaviour, VOSviewer, Bibliometric, Economic Agents, Households, Financial Services Market, Scopus, Web of Science Core Collection.

Received: July 4, 2021. Revised: December 6, 2021. Accepted: January 12, 2022. Published: January 14, 2022. 


\section{Introduction}

Development of the financial services market is an important component for ensuring stable and progressive development of the national economy. Each country is trying to create such conditions for the financial services development, the availability of which will improve the quality of work, especially of financial institutions, increase the efficiency of their work through continuous improvement of their own activities. A special role in the development of the financial services market is played by households, which are able to ensure the financial system functioning of the state through temporary use by credit and investment institutions of their funds. In the vast majority of developed countries it is the funds of population that are the basis for the development of the national economy, form a stable and longterm financial resource for economic development [1].

The leading role of households' funds in the development of the national economy is also important from the standpoint of these resources stability in the financial system of the state [2]. In fact, the formation of adequate and clear rules for the work of financial institutions, which play an indirect role between the owners of funds and those entities that need them, allows to ensure the effectiveness of the transformation mechanism by transforming financial resources of households into credit and investment funds [3], [4]. However, the complexity of the outlined mechanism due to the involvement of a large number of economic agents, among which households play an important role, makes this mechanism vulnerable to various dissipative, turbulent factors, processes may occur in the households' financial system and in the financial system of the country in general [5-6]. The complexity of the situation is exacerbated by the fact that predicting the actions of households from the standpoint of the system analysis within the country is quite difficult, and sometimes impossible, given the wide range of individual factors that affect each person in making their own financial decisions [7-9].

Today, the financial market, the financial services market develop in rather difficult, transformational conditions of own functioning. The main reason for this against the background of basic traditional reasons (economic downturn, rising unemployment, changes in raw materials, goods, etc.) are informatization processes [10-14], digitalization [15-20], innovation renewal [21-29], active introduction of the latest technologies in all spheres of these markets functioning. Accordingly, these processes affect the development of households, processes of their own financial decisions-making, form new requirements to the work of financial institutions, financial products and services. These processes will continue in the future, and that is why the issues of conducting research in this sphere, systematizing the results that have already been obtained by scientists are becoming relevant.

However, as at the beginning of any study, there is always a categorical vacuum and the need to clarify, to specify and find new approaches to understanding the object of the study. It is quite clear that as of today economics has already formed a powerful system of economic categories that have their own ontological connections, a logical structure that allows them to be considered as a holistic, universal space of economic knowledge. However, this system is constantly evolving. That is why the traditional question arises when conducting research in fairly new areas of economics, which include behavioral finance [30-32], namely: what is financial behavior as an economic, financial category and why today it is important to study its essence [33]. Issues of studying the nature and structure of financial behavior of households, current state of conducting researches in this sphere are of particular relevance. Thus, the purpose of the article is to study the trends in the study of financial behavior, conducting a bibliographic analysis of this category.

\section{Literature review}

It is well known among economists that research in the field of knowledge of the peculiarities of various models formation of the economic agents' behavior began to be actively conducted in the late twentieth century and gained considerable popularity. This situation is primarily due to the fact that within new conceptual provisions put forward by scientists the attempt is made to explain those economic processes and phenomena, which could not have been explained so far by classic, traditional theories [34-36].

On the other hand, new concepts have not only given an understanding of what is happening in the financial market, within individual economic systems, but also have put forward and successfully proved new hypotheses and concepts based on the results of numerous experiments, surveys, sociological studies in which thousands of respondents were involved. It is the synthesis of methodological constructions of several sciences that allowed economists to gain new knowledge and, most important, to adapt it for practical use in the work of financial institutions, to form new 
approaches to the regulation of financial relations. Considerable attention in the process of studying behavior of economic agents and the possibility of influencing it was paid namely to psychological aspects of their decision making on the management of their own financial resources [7; 37-42]. Thus, the theory of behavioral finance was gradually formed.

In the theory of behavioral finance in the late twentieth century, a significant amount of research was conducted on the behavior of households and other economic agents in different types of financial markets. The results of these studies confirmed that people's behavior is not rational in making financial decisions, can be spontaneous, illogical and unpredictable [39; 43-45]. Accordingly, it complicates the processes of modeling the functioning and development of the financial market, markets of individual financial assets, even in the conditions of relatively stable economic development in the country [36; 46-48].

However, in a significant number of papers by scientists in the field of behavioral economics, much attention is paid primarily to the study of peculiarities of the formation and transformation of the behavior of investors [6; 49-51], who are active in the stock market either independently, or using the services of professional financial advisors. Nagy \& Obenberger [52] paid significant attention in their research to the identification and description of the characteristics of the influence of various factors on the formation of different types of investors' behavior. The outlined issues are reflected in scientific works of Lodhi [49], Sarwar and Afaf [50]. Orden-Cruz and Díaz-Iglesias [53] carried out the bibliometric analysis of the investors' protection. Jureviciene and Jermakova [54] investigate the impact of financial behavior of individuals on investment decisions made by them. Thus, within many scientific researches it is very often possible to meet the identification of concepts of financial and investment behavior, in other case, the researches at all do not give own definition of the financial behavior essence. Accordingly, the question arises: and in the countries where the stock market is not developed, what model of financial behavior is inherent in economic agents and how is it formed? These issues among a significant number of scientific papers in the field of financial behavior are not sufficiently clear.

In general, in the field of studying financial behavior, a number of studies have already been conducted, but all of them are fragmentary in nature and reveal some features of this concept. For example, O'Neill and Xiao [55] carried out a thorough study based on the results of online surveys of the peculiarities of the financial behavior formation of households before a financial crisis in 2007 and afterwards. More than 10,000 respondents took part in the survey. The authors highlight both negative and positive consequences of this crisis, which affected the behavior of citizens in the credit and deposit markets. Fred van Raaij [56] conducts a detailed analysis of the formation of irrational and rational behavior of the consumers of financial services, determines the importance of marketing tools in shaping the model of this behavior, considers specific features of citizens' behavior in different financial services markets (Saving Behavior; Credit Behavior; Insurance Behavior; Investment Behavior; Tax Behavior; Responsible Financial Behavior). Madrian [57] focus on the public focus features in the field of regulation of financial institutions, the prevention of financial fraud and combating financial fraud in order to create conditions for the formation of rational financial behavior of citizens in evolving them in further transformation into investment resources. Strömbäck [51; 58] focus on the study of the financial behavior model, individual internal factors of the person that influence its formation. The authors pay considerable attention to the issues of self-control in spending money, rationality in their own costs, optimism, and deliberative thinking.

In the process of the financial behavior study, special attention is paid by scientists to the issues of financial literacy and its role in shaping financial behavior of households. Carlo de Bassa Scheresberg [6] examines the role of financial literacy in shaping financial behavior of young people. The outlined matters were also investigated by Lajuni [59], who studied the impact of religion, financial knowledge on the formation of financial behavior among millennial generation and specific features of the emergence of financial difficulties by them. Special attention is paid to financial behavior of the youth in scientific works of A. da Silva [60]; Marcellia [61]; Deventer [62]. Within the paper of Daqar [63], the issues of the attitude of Millennials and generation $\mathrm{Z}$ to Fintech and the impact of these technologies on the formation of their financial behavior are studied. In addition, research in the field of the financial literacy impact on the formation of financial behavior of households and certain categories of citizens was carried out by Hasibuan [64]; Andarsari and Ningtyas [65]; Rai [66]; Arifin [67]. For example, Komara [68] study in their work features of the financial literacy impact on financial decision-making in Indonesia. 
There is a significant amount of scientific works in the field of describing financial behavior of the citizens of specific countries. In particular, Sudindra [69] considers financial decision-making by households and conducts an empirical study of the formation of the financial behavior model of 378 working women serving in information technology services in India. Zulaihat and Widyastuti [70] conduct research on the factors influencing on the financial behavior formation of households in Indonesia. The scientists carry out online survey of citizens and use 21 indicators to describe the financial behavior model. Jurevicienè and Gausienè [71] investigate the peculiarities of the financial behavior formation in Lithuania and state that citizens mostly strive to meet short-term goals and do not care about savings for retirement, do not use all available investment instruments to increase their savings. Xiao and Porto [72] consider the formation of financial behavior in China. The authors as a result of the study conclude that most citizens form a model of financial behavior, in which they prefer current costs than savings. Ismail [73] carried research in the field of The Relationship between Financial Attitude and Financial Goal Towards Financial Behaviour, which was implemented on the base of a survey of citizens in Malaysia. The study proved that financial attitude is significant to financial behaviour.

However, despite numerous scientific works of scientists, systematic theoretical and methodological research in this area, as noted, is absent, which updated this area of research and justified the need for conceptual analysis of the state of scientific developments in the study of financial behavior. This contributed to the choice of the article's topic.

Preliminary analysis of the state of scientific developments in the field of knowledge of the nature and peculiarities of the model formation of financial behavior showed that there is a large number of scientific papers that analyze the state of scientific developments in general in the field of financial behavior. For example, Paule-Vianez [74] in the paper "A bibliometric analysis of behavioural finance with mapping analysis tools" consider the works for the period 1987-2017 in the sphere of the irrational investors' behavior and its impact in financial markets, and highlight 13 directions in the behavioral finances sphere, namely: Investor sentiment, disposition effect, Overconfidence and Expected Return Stocks as motor themes; Arbitrage, Biasand Model as basic and transversal themes; OPI, Weather and Mutual Funds as specialized themes; Strategies, Attention and Portfolio Selection as emerging or declining themes. The authors state that issues of the investment behavior analysis are central among the works in this area. Fakhry [75] provides a literature review of the behavioral finance theory and analyses existing theories to explain the mechanism of the investors' response to information on how asset prices are formed in investment markets. The author notes that determining or forecasting such prices is tentatively possible only using both traditional theories of the explanation of price settings in the financial market, and by taking into consideration certain provisions of behavioral finance. Joo and Durri [76] investigate the state of research by analyzing the psychological factors impact on the decision-making process of investors. Pimenta and Famá [77] review scientific papers in the field of behavioral finance from 1993 to 2012 , study the most cited scientific papers [7895], the number of authors, scientific publications where they are published.

However, given that the range of different areas in the behavioral finance theory is quite significant, it is the matter of specifying the essence of financial behavior, the study of the scientific works state in this field is not given due attention. Therefore, we will try to answer the following questions:

RQ1: is the number of scientific papers by studying financial behavior sufficient, given high level of the scientists' interest in conducting research in the field of financial behavior?

RQ2: is there systematic and thorough scientific research that would form a holistic theoretical basis for further research of financial behavior, whether its essence and ways to describe its forms are specified?

RQ3: are the issues of financial behavior mostly studied in the countries where the stock market is developed, and does the research focus primarily on studying investment behavior of economic agents?

\section{Methodology}

The methodological basis of the study is a range of general scientific research methods, which include observation, measurement, and comparison. The methodology of the system approach, comparative analysis, statistical research methods is being actively used. The VOSviewer toolkit was used to visualize analytical information. MS Excel functions were used for corresponding graphic analytical researches.

The information base of the research is the results of analytical study of the data of information retrieval functionalities of Scopus and Web of Science scientific platforms on the number of publications in the field of financial behaviour research. The availability of this information 
allowed us to single out all articles in the entire scientific array of scientific publications, which, firstly, concerned the study of in the field of behavioral finance in general and, secondly, to analyze in detail the state of research exclusively in the field of financial behavior. This was done by defining a sample of scientific papers according to the following criteria: simultaneous use of the words "financial" and "behavior" exclusively in the title of the article; the period is 1970-2020. For such parameters as scientific field, type of documents, sources of publications, country, additional selection parameters were not used. A similar approach was used to search for publications in two databases, namely: Scopus and Web of Science.

The application of grouping and comparative analysis methods as well allowed to conduct research on the main scientific areas within which the study financial behavior are researched, and analyze the countries in which the world's major research centers are concentrated where the above issues are studied.

\section{Results and Discussion}

Understanding the essence of financial behavior as a universal category is the first step towards finding new methodological concepts for studying behavior of economic entities in the financial services market, identifying the features of its change in the digitalization era, specifying new threats and benefits for customers that have digitalization processes of the financial services sphere, understanding the differentiation of the financial behavior model between different generations, countries.
The potential of the behavioral economy theory was really extremely large, and this is confirmed by a large number of scientific works that have been done in this area for recent 50 years (Fig. 1).

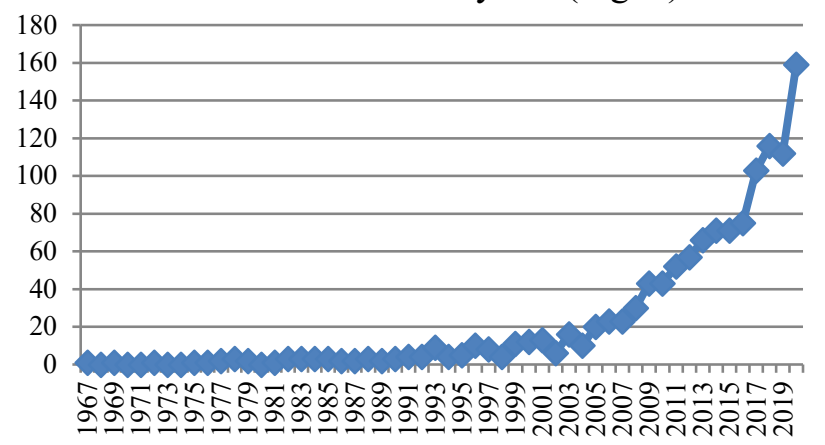

Figure 1. Number of publications in the Scopus data in the behavioral finances sphere

Source: compiled by the authors based on the analysis of the Scopus database

Actually, the data in Fig. 1 confirm active development of research in the field of financial economy and behavioral finance. If in 1970 in the Scopus database, only one paper was registered in this field, then in $1980-4$ works, in $1990-7$ works, and already in $2000-20$ publications, in 2010 - 165 works, and in $2019-488$ scientific works. It is worth noting that most of these studies were conducted by scientists working in the countries with developed financial markets, and this was also one of the reasons for active development of research in this area.

In Fig. 2, a cognitive model of the interaction between key words in publication relating research of individual issues in the sphere of behavioral finance is presented. 


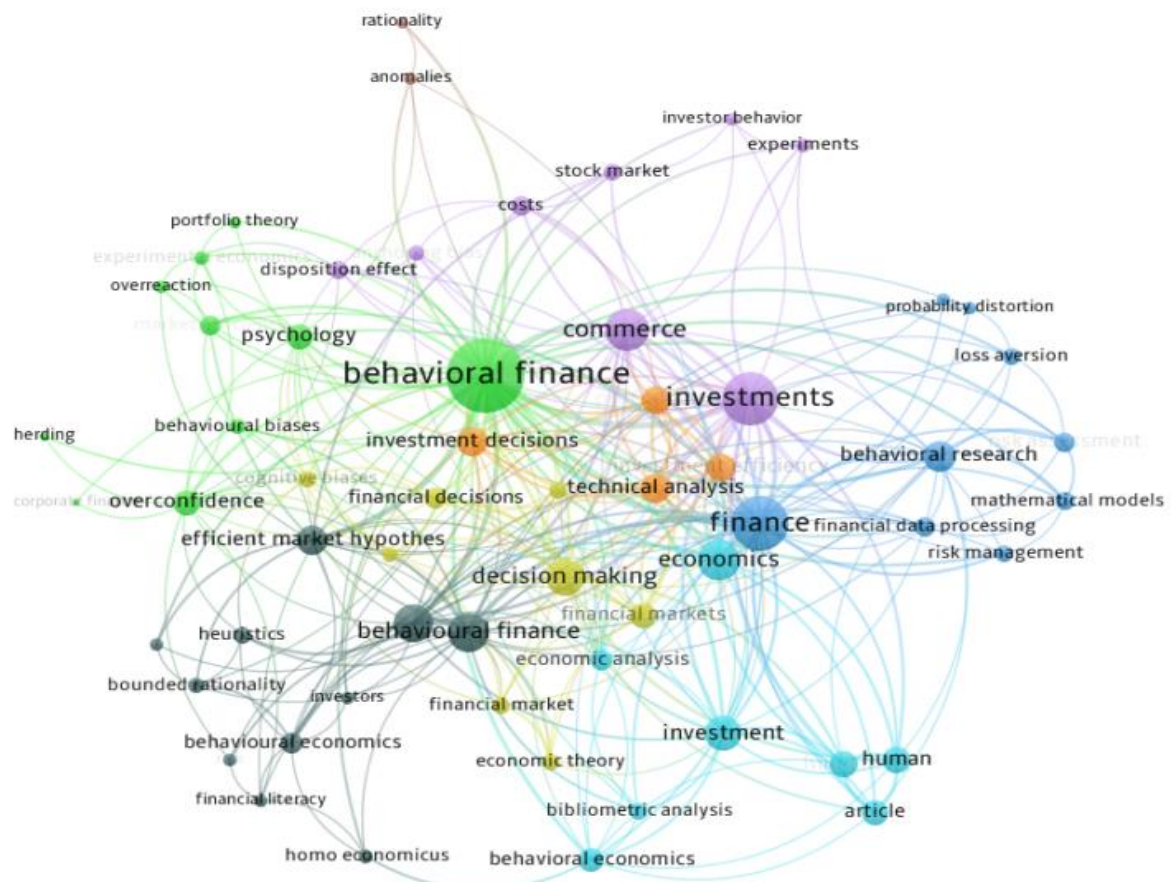

Figure 2. Graphic map of the interaction between key words in publications relating research in behavioral finance sphere

Source: compiled by the authors based on the analysis of the Scopus database and using tools of the VOSviewer program

In Fig. 2, a cognitive model of the interaction between key words in publication relating research of individual issues in the sphere of behavioral finance is presented.

Therefore, analyzing the information in Fig. 2, we can say that in publications relating to the study of certain aspects of the behavioral finance direction, scientists pay the most attention to the following spheres: investing, e-commerce, financing, making investment and financial decisions in general, and scientific issues of the analysis of the behavior models of economic agents. In total, this sample included 60 key words that are most often mentioned in publications on behavioral finances. We'd also like to note that the behavioral finances field is of great significance today, and within relevant researches, a very large list of problems by ensuring the efficiency of financial markets, the formation of appropriate institutional support for their development, the search for optimal models in first turn of investment behavior, is being studied.

However, the analysis of the financial behavior essence as a complex economic category, as noted, is insufficiently studied even within the above publications. The data of Fig. 3 confirm insufficient study within the behavioral economy theory namely on the issues of the essence concretization of essence of the category "financial behavior".

The data in Fig. 3 allow us to conclude that the number of scientific papers, which titles contain the words "financial" and "behavioral", is also growing in line with the number of scientific publications in the behavioral economy field.

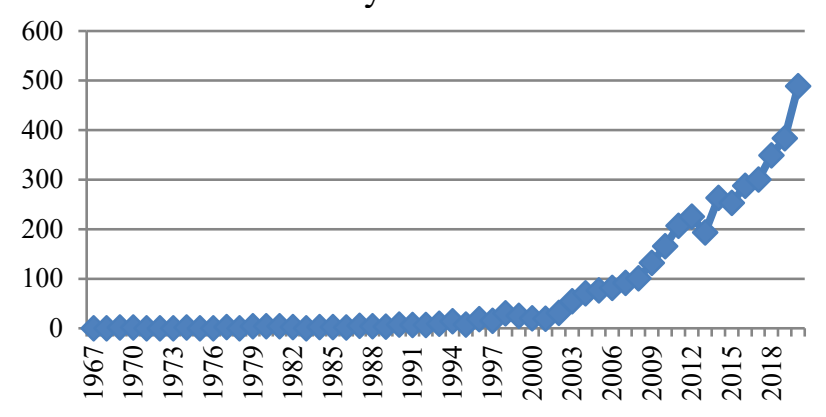

Figure 3. Number of scientific publications, in which titles the words "financial" and "behavioral" are simultaneously met

Source: compiled by the authors based on the analysis of the Scopus database

If in 1972 in the Scopus database only one paper was registered in this sphere, then in 1981 - 1 work, in $1991-4$ works, and already in $2001-12$ publications, in 2011 - 52 works, and in $2019-112$ scientific works. This tendency is also confirmed by the analysis of the number of scientific publications, in which titles the words "financial" and "behavior" are simultaneously met, and which are kept in the Web of Science database (Fig. 4). 


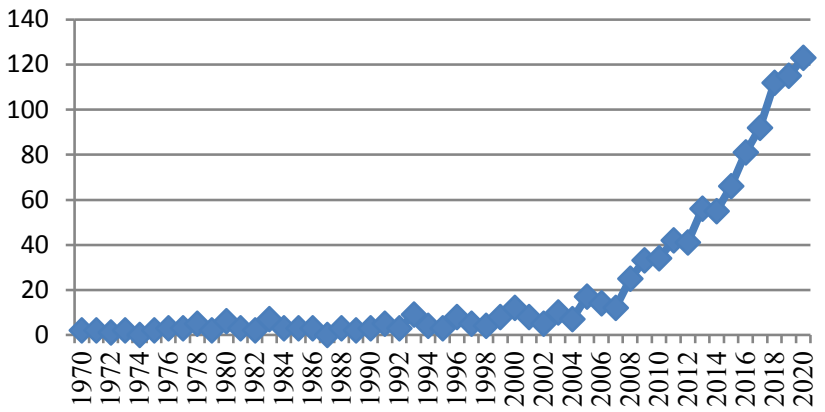

Figure 4. Number of scientific works, in which titles the words "financial" and "behavior" are simultaneously met

Source: compiled by the authors based on the analysis of the Web of Science database

Accordingly, if in 1972 only one work in this sphere was registered, in 1981 - 3 works, in 1991 5 works, then in 2001 - already 8 publications, in 2011 - 42 works, and in 2019 - 115 scientific works.

The outlined statistical data also confirm the relevance of the study of the financial behavior essence, increasing the interest of scientists to this phenomena research, peculiarities of the formation of its various models. However, the number of publications in this sphere remain insignificant, even compared to the array of works in the field of behavioral finance in general.

In Fig. 5, information on the proportion of scientific publications that deal with both words "financial" and "behavior" in the total number of papers related to the behavioral finance research is presented.

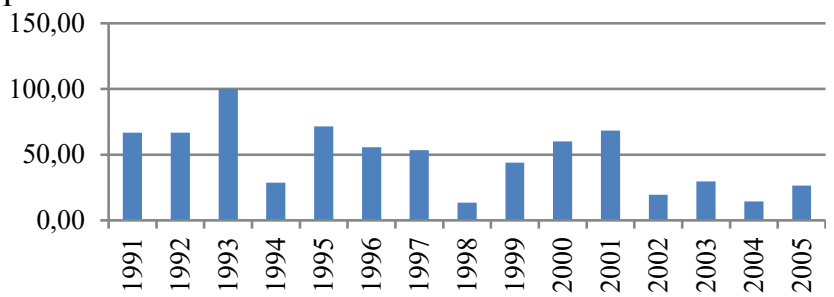

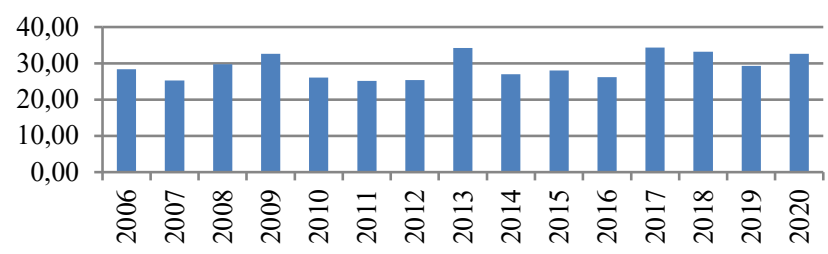

Figure 5. The share of scientific publications, in which titles the words "financial" and "behavior" in the total number of works relating the financial behavior research are simultaneously met

Source: compiled by the author based on the analysis of the Scopus database

The data in Fig. 5 show that, on average, only $35.0 \%$ of scientific publications devoted to the study of behavioral finance also relate to the consideration of certain provisions of financial behavior.

This only confirms the fact of insufficient research of this part of the behavioral economy theory. Although, in our opinion, the very understanding of the essence of financial behavior, its peculiarities and types is the most important component of the whole theory of behavioral finances. In Fig. 6, a graphic map of key words, in which topics the words "financial" and "behavior" are met, is presented.

Let's consider in detail current trends in the study of financial behavior through the analysis of scientific publications in this field. As already mentioned, the methodology of behavioral economy is synthesizing and is based on a combination of research methods of economy, sociology and psychology.

This only confirms the fact of insufficient research of this part of the behavioral economy theory. Although, in our opinion, the very understanding of the essence of financial behavior, its peculiarities and types is the most important component of the whole theory of behavioral finances. In Fig. 6, a graphic map of key words, in which topics the words "financial" and "behavior" are met, is presented. 


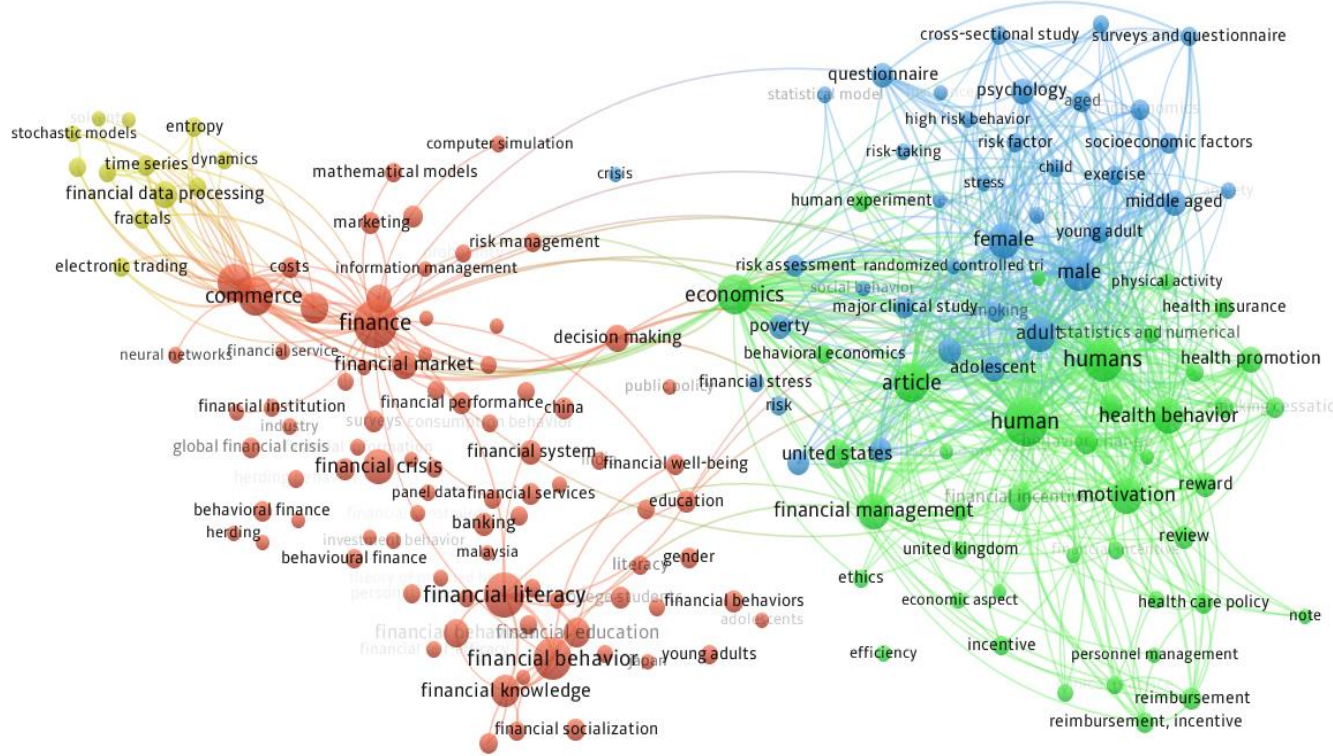

Figure 6. Graphic map of key words in publications, in which topics the words "financial" and "behavior" are simultaneously met

Source: compiled by the author based on the analysis of the Scopus database and using the tools of the VOSviewer program

Let's consider in detail current trends in the study of financial behavior through the analysis of scientific publications in this field. As already mentioned, the methodology of behavioral economy is synthesizing and is based on a combination of research methods of economy, sociology and psychology.

This combination has allowed scientists to form a different view on the functioning of classical processes and systems, especially to explain how households behave and change when making decision about using their own financial resources, and how to use them in the best way to generate income in long run.

It is interdisciplinary nature of behavioral economy that explains the existence of scientific publications on the study of financial behavior in completely different fields of study. In Table 1, relevant information is presented.

Table 1. Number of publications by spheres of scientific research

\begin{tabular}{|c|c|c|c|c|c|}
\hline $\begin{array}{c}\text { Po } \\
\text { s. } \\
\text { No }\end{array}$ & Science & $\begin{array}{c}\text { Number } \\
\text { of } \\
\text { publicatio } \\
\text { ns }\end{array}$ & $\begin{array}{l}\text { Pos. } \\
\text { No. }\end{array}$ & Science & $\begin{array}{c}\text { Number } \\
\text { of } \\
\text { publicatio } \\
\text { ns }\end{array}$ \\
\hline \multicolumn{3}{|c|}{ Sphere of behavioural finances in general } & \multicolumn{3}{|c|}{$\begin{array}{c}\text { Publications, in which titles the words "financial" and } \\
\text { "behaviour" are met }\end{array}$} \\
\hline 1 & $\begin{array}{l}\text { Economics, Econometrics and } \\
\text { Finance }\end{array}$ & 2082 & 1 & $\begin{array}{l}\text { Economics, Econometrics and } \\
\text { Finance }\end{array}$ & 555 \\
\hline 2 & $\begin{array}{lll}\text { Business, } & \text { Management } & \text { and } \\
\text { Accounting } & & \\
\end{array}$ & 1259 & 2 & $\begin{array}{lll}\text { Business, } & \text { Management } & \text { and } \\
\text { Accounting } & & \\
\end{array}$ & 397 \\
\hline 3 & Computer Science & 609 & 3 & Social Sciences & 270 \\
\hline 4 & Social Sciences & 568 & 4 & Psychology & 143 \\
\hline 5 & Psychology & 534 & 5 & Computer Science & 126 \\
\hline 6 & Engineering & 348 & 6 & Medicine & 105 \\
\hline 7 & Mathematics & 322 & 7 & Mathematics & 93 \\
\hline 8 & Medicine & 309 & 8 & Engineering & 84 \\
\hline 9 & Decision Sciences & 280 & 9 & Physics and Astronomy & 61 \\
\hline 10 & Environmental Science & 104 & 10 & Decision Sciences & 50 \\
\hline 11 & Arts and Humanities & 87 & 11 & Arts and Humanities & 45 \\
\hline 12 & Physics and Astronomy & 67 & 12 & Environmental Science & 44 \\
\hline 13 & Energy & 62 & 13 & Agricultural and Biological Sciences & 27 \\
\hline 14 & Multidisciplinary & 60 & 14 & Multidisciplinary & 22 \\
\hline
\end{tabular}




\begin{tabular}{|c|l|c|c|l|c|}
\hline 15 & Neuroscience and Biological & 49 & 15 & Energy & 21 \\
\hline 16 & $\begin{array}{l}\text { Agricultural and } \\
\text { Sciences }\end{array}$ & 16 & $\begin{array}{l}\text { Biochemistry, Genetics } \\
\text { Molecular Biology }\end{array}$ & 17 \\
\hline 17 & Nursing & 42 & 17 & Earth and Planetary Sciences & 12 \\
\hline 18 & Earth and Planetary Sciences Genetics and & 41 & 18 & Materials Science & 9 \\
\hline 19 & $\begin{array}{l}\text { Biochemistry, } \\
\text { Molecular Biology }\end{array}$ & 24 & 20 & Nursing & 7 \\
\hline 20 & Materials Science & 19 & Neuroscience & 7 \\
\hline
\end{tabular}

Source: compiled by the authors based on the analysis of the Scopus database

Thus, the data in Table 1 confirm that scientific works in the financial behavior sphere occur in many scientific fields. We'd like to note that within this analysis, first of all, publications in the Scopus database, in which titles the words "financial" and "behaviour" are met, were took into consideration. It is quite logical that the majority of these publications were in the sphere of Economics, Econometrics and Finance (2082 and 555) and Business, Management and Accounting (1259 and 397). This situation is common for behavioral finances and research in financial behavior. In addition, the data in Table 1 allow us to conclude that a considerable number of scientific publications relating behavioral finances were written in the sphere of Computer Science (609), Social Sciences (568), Psychology (534). However, the majority of research of financial behavior was carried out in Social Sciences (270), Psychology (143), Computer Science (126). Accordingly, the share of scientific publications that study financial behavior in the total number of scientific works in the behavioral finances field is as follows: Economics,
Econometrics and Finance - 26,7 \%; Business, Management and Accounting - 31,5\%; Social Sciences - 47,5\%; Psychology - 26,8 \%; Computer Science $-20,7 \%$ (see Table 1).

The structure of publications in the Web of Science database by spheres, in which individual aspects of financial behaviour are researched, is as follows: Economics - 385 pcs.; Business Finance 182 pcs.; Business - 175 pcs.; Management - 129 pcs. In other scientific fields, the number of publications is relatively small. However, the number of such scientific fields remains quite significant, which confirms the interdisciplinary potential of relevant research.

Let's carry out the analysis on the distribution of the number of publications, in which titles the words "financial" and "behavior" are met by countries, in which these publications were published. First, the leaders in this research are scientists from the USA - 371 publications, Great Britain - 114 publications and China -113 publications.

In Table 2, the more detailed distribution of relevant publications by countries is presented..

Table 2. Number of publications, in which titles the words "financial" and "behavior" are simultaneously met

\begin{tabular}{|c|l|c|c|l|c|}
\hline Pos. No. & Country & $\begin{array}{c}\text { Number of } \\
\text { publications }\end{array}$ & Pos. No. & \multicolumn{1}{c|}{ Country } & $\begin{array}{c}\text { Number of } \\
\text { publications }\end{array}$ \\
\hline 1 & United States & 371 & 13 & Canada & 32 \\
\hline 2 & $\begin{array}{l}\text { United } \\
\text { Kingdom }\end{array}$ & 114 & 14 & South Korea & 32 \\
\hline 3 & China & 113 & 15 & Spain & 27 \\
\hline 4 & Germany & 50 & 16 & Russian Federation & 24 \\
\hline 5 & Malaysia & 46 & 17 & Japan & 23 \\
\hline 6 & Netherlands & 46 & 19 & Turkey & 23 \\
\hline 7 & Australia & 40 & 20 & Brazil & 16 \\
\hline 8 & Italy & 39 & 21 & Sweden & 16 \\
\hline 9 & India & 37 & 22 & Greece & 13 \\
\hline 10 & France & 36 & 23 & South Africa & 12 \\
\hline 11 & Taiwan & 36 & 24 & Poland & 12 \\
\hline
\end{tabular}

Source: compiled by the authors based on the analysis of the Scopus database

In addition, in Fig. 7, the relationship between the authors of scientific publications in the financial behavior field, who conduct research at educational and research institutions in different countries of the world, is shown. 


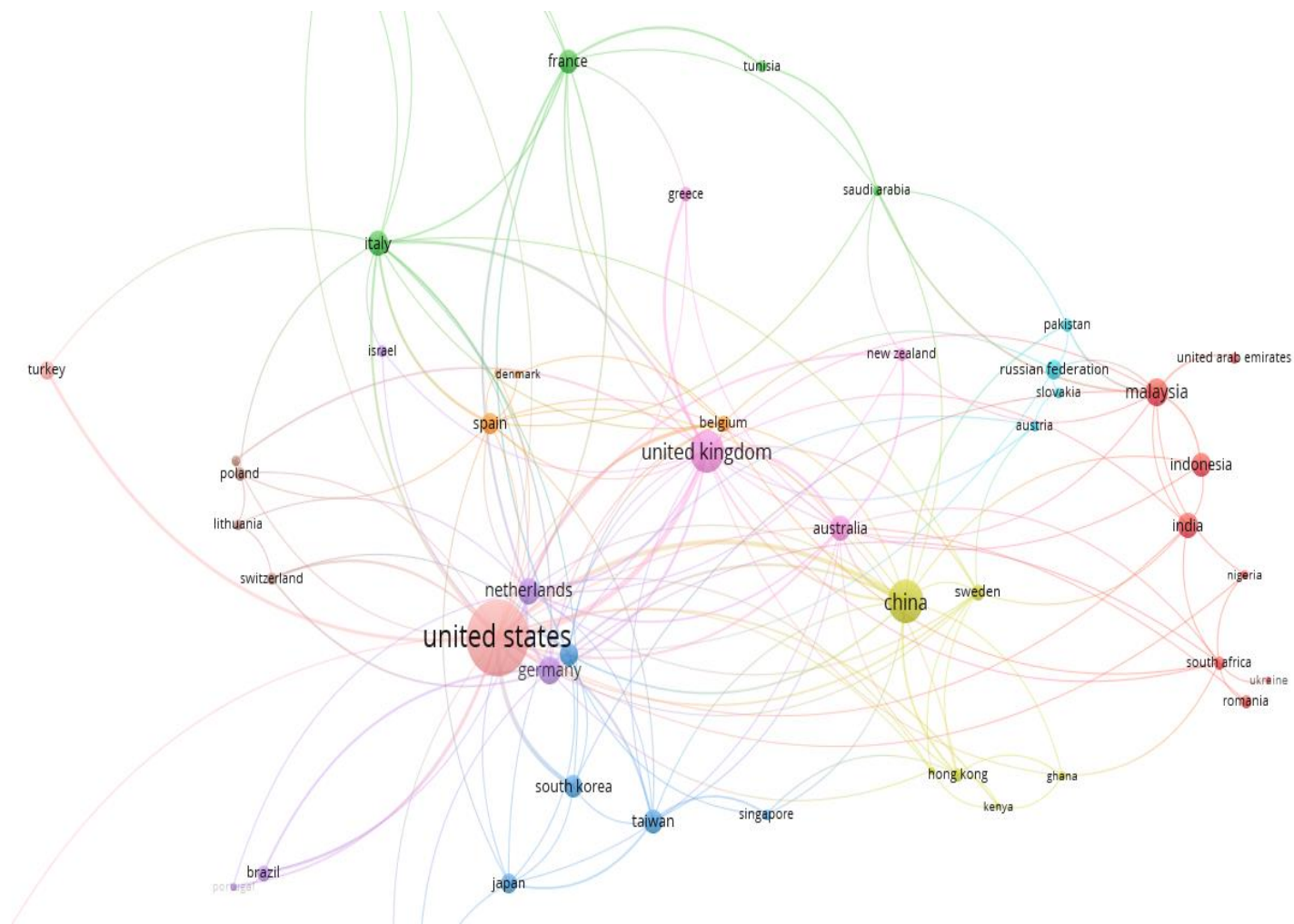

Figure 7. Graphic map of the interrelation between scientists of different countries, who conduct their research in the financial behavior sphere

Source: compiled by the authors based on the analysis of the Scopus database and using the tools of the VOSviewer program

The analysis of first ten positions on the number of publications in the financial behavior field shows that this area is actively studied in European countries (Germany - 50 publications; the Netherlands - 46 publications; Italy - 39 publications; France - 36 publications). Increased interest in these studies is observed in countries such as Malaysia, Australia, India, Taiwan, and Indonesia. This indicates a global trend of increased interest of scientists in the study of theoretical provisions of the financial behavior essence, the search for new methods for its study. All this is due to awareness of the importance of the behavioral aspects understanding by population in the financial sector, the possibility of using new knowledge in this area to prevent destructive, systematic and financial crises, identifying their preconditions.

The analysis of first ten positions on the number of publications in the financial behavior field shows that this area is actively studied in European countries (Germany - 50 publications; the Netherlands - 46 publications; Italy - 39 publications; France - 36 publications). Increased interest in these studies is observed in countries such as Malaysia, Australia, India, Taiwan, and Indonesia. This indicates a global trend of increased interest of scientists in the study of theoretical provisions of the financial behavior essence, the search for new methods for its study. All this is due to awareness of the importance of the behavioral aspects understanding by population in the financial sector, the possibility of using new knowledge in this area to prevent destructive, systematic and financial crises, identifying their preconditions.

\section{Conclusion}

Thus, within the article, the current state of research in in the field of knowledge of the financial behavior essence is considered. It is established that up to date the scientists have already formed a significant array of scientific publications in the behavioral finance field. However, only some of them study the essence of financial trust from a theoretical point of view, describing ontological characteristics of this behavior, determining the specific features of the behavior of individual economic agents in financial markets.

The use of analytical tools of the Scopus and Web of Science scientometric databases allowed to analyze publishing activity in the financial behavior study, the identify the basic world centers where such research is conducted. The analysis of 
scientific works from 1967 to 2019 gives grounds to assert active development of research in the behavioral finance field, especially starting from 1999-2000. An important role in increasing the scientists' interest in this topic was played by the global finance crisis of 2007-2008, which confirmed that scientists know quite a bit about the peculiarities of financial behavior of different economic agents. Rather destructive impact of the mentioned crisis on the financial security level of households also played a positive role in the increase of scientific publications that studied financial behavior of citizens in different conditions of economic development.

The analysis of information of the Scopus database suggests a significant increase in the number of scientific papers in 2003-2019, in which titles the words "financial" and "behavior" are met, as well. If in 2001, there were 12 publications of this kind, then in 2011 - 52 papers, and in 2019 - already 112 scientific works. This tendency also gives grounds to claim that the scientists' interest in conducting research in this direction will only increase.

In addition, within the article, the analysis of scientific directions within which research of financial behavior is carried out, and it is established that the majority of these publications were written in the sphere of Economics, Econometrics and Finance 555) and Business, Management and Accounting (397). Among countries, the above direction is being mostly directed in the USA, Great Britain and China.

Therefore, further research, in our opinion, should determine the essence of financial behavior as a separate category, a description of its features and factors of formation. There is also a need to develop a single concept for describing the financial behavior model among citizens of individual countries, and individual social groups. It is quite logical that financial behavior from a theoretical and methodological point of view is a very complex and multifaceted phenomenon, many aspects of which today require new research.

\section{Acknowledgment}

This research is carried out within the framework of the scientific project "Transformation of households' behaviour in the financial services market in the context of digitalization" with the support of the Ministry of Education and Science of Ukraine.

\section{References:}

[1] B. R. Avery \& A. B. Kennickell, "Household saving in the U.S.," Review of Income and Wealth, 37(4), 409-432, 1991.

[2] L. Shkvarchuk \& R. Slav'yuk, "The Financial Behavior of Households in Ukraine," Journal of Competitiveness, 11(2), 144-159, 2019. https://doi.org/10.7441/joc.2019.03.09

[3] A. H. Marianne \& M. H. Jeanne, "Household Financial Management: The Connection between Knowledge and Behavior," Federal Reserve Bulletin, 309-322, 2003. URL: https://www.federalreserve.gov/pubs/bulletin/2 003/0703lead.pdf

[4] S. Shkarlet \& M. Dubyna, "Features of the cognitive approach application to the essence of the financial services market identification," Economic Annals-XXI, 158(3-4(2)), 70-74, 2016. http://dx.doi.org/10.21003/ea.V158-16

[5] L. Marina, N. Irawati, I. Sadalia \& I. Muda, "The Financial Behavior Traits Impact On Financial Distress At Small Medium Enterprises (The Relationships Between The Industry And Sustainable Development In Indonesia)," International Journal of Scientific \& Technology Research, 8(04), 27-30, 2019.

[6] N. Suppakitjarak \& P. Krishnamra, "Household Saving Behavior and Determinants of the Forms of Saving and Investment in Thailand," Journal of Economics, Business and Management, 3(3), 326-330, 2015. https://doi.org/10.7763/JOEBM.2015.V3.204

[7] B. Dervishaj, "Psychological Biases, Main Factors of Financial Behavior - A Literature Review," European Journal of Natural Sciences and Medicine, 2(2), 54-64, 2018. URL:

https://journals.euser.org/files/articles/ejmn_v2 i2/Dervishaj.pdf

[8] P. Dolan, A. Elliott, R. Metcalfe \& I. Vlaev, "Influencing Financial Behavior: From Changing Minds to Changing Contexts," Journal of Behavioral Finance, 13(2), 126-142, 2012.

https://doi.org/10.1080/15427560.2012.680995

[9] Ye. Polishchuk, S. Onikiienko, A. Ivashchenko, A. Kornyliuk \& N. Demchyshak, "Prior credit assessment of long-term SME projects with non-standard cash flows," Banks and Bank Systems, 16(2), 148-158, 2021. https://doi.org/10.21511/bbs.16(2).2021.14

[10] N. Kholiavko, T. Chekhovych, O. Mirshuk \& V. Vovk, "Integrated model of the competitive higher education: Legal, economic and psychopedagogical aspects," International Journal of Industrial Engineering and Production 
Research, 31(4), 535-545, 2020. https://doi.org/10.22068/ijiepr.31.4.535

[11] N. Kholiavko, L. Popova, M. Marych, I. Hanzhurenko, S. Koliadenko \& V. Nitsenko, "Comprehensive methodological approach to estimating the research component influence on the information economy development," Naukovyi Visnyk Natsionalnoho Hirnychoho Universytetu, (4), 192-199, 2020. https://doi.org/10.33271/nvngu/2020-4/192

[12] O. Lagovska, V. Ilin, M. Kotsupatriy, M. Ishchenko \& L. Verbivska, "Priority directions of tax policy change in the information sphere," Naukovyi Visnyk Natsionalnoho Hirnychoho Universytetu, (3), 183-190, 2020. https://doi.org/10.33271/nvngu/2020-3/183

[13] K. Shaposhnykov, O. Kochubei, O. Grygor, N. Protsenko, O. Vyshnevska \& A. Dzyubina, "Organizational and Economic Mechanism of Development and Promotion of IT Products in Ukraine," Estudios de economía aplicada, 39(6), 2021. https://doi.org/10.25115/eea.v39i6.5264

[14] O. Zybareva, L. Verbivska, I. Lopashchuk, O. Kalaman, T. Derkach \& N. Smentyna, "Strategically-oriented enterprise management through information systems," International Journal of Recent Technology and Engineering, 8(2), 3014-3017, 2019. https://doi.org/10.35940/ijrteB2900.078219

[15] C. de Bassa Scheresberg, "Financial Literacy and Financial Behavior among Young Adults: Evidence and Implications," Numeracy, 6(2), 5, 2013. http://dx.doi.org/10.5038/19364660.6.2.5

[16] H. Carlsson, S. Larsson, L. Svensson \& F. Astrom, "Consumer Credit Behavior in the Digital Context: A Bibliometric Analysis and Literature Review," Journal of Financial Counseling and Planning, 28(1), 76-94, 2017. http://dx.doi.org/10.1891/1052-3073.28.1.76

[17] M. Dubyna, A. Zhavoronok, N. Kudlaieva \& I. Lopashchuk, "Transformation of household credit behavior in the conditions of digitalization of the financial services market," Journal of Optimization in Industrial Engineering, 14(1), 97-102, 2021. https://doi.org/10.22094/JOIE.2020.677835

[18] M. M. Gobble, "Digitalization, Digitization, and Innovation," Research-Technology Management, 61(4), 56-59, 2018.

[19] S. Shkarlet, M. Dubyna, K. Shtyrhun \& L. Verbivska, "Transformation of the Paradigm of the Economic Entities Development in Digital Economy," WSEAS Transactions on
Environment and Development, 16, 413-422, 2020.

[20] M. Zveryakov, V. Kovalenko, S. Sheludko \& E. Sharah, "FinTech sector and banking business: competition or symbiosis?" Economic Annals-XXI, 175(1-2), 53-57, 2019. https://doi.org/10.21003/ea.V175-09

[21] O. Popelo, S. Tulchynska, O. Garafonova, L Kovalska., S. Khanin, "Methodical approach to assessing innovative development efficiency of regional economic systems in the conditions of the creative economy development," WSEAS transactions on environment and development, 17, 685-695, 2021. https://doi.org/10.37394/232015.2021.17.66

[22] S. Tulchynska, O. Popelo, O. Vovk, B. Dergaliuk, I. Kreidych, T. Tkachenko, "The Resource Supply of Innovation and Investment Strategies of the Microeconomic Systems Modernization in the Conditions of Digitalization," WSEAS transactions on environment and development, 17, 819-828, 2021. https://doi.org/10.37394/232015.2021.17.77.

[23] O. Vovk, M. Kravchenko, O. Popelo, S. Tulchynska, M. Derhaliuk, "Modeling the Choice of the Innovation and Investment Strategy for the Implementation of Modernization Potential," WSEAS transactions on systems and control, 16, 430-438, 2021. https://doi.org/10.37394/23203.2021.16.38.

[24] O. Popelo, S. Tulchynska, V. Marhasova, N. Ivanova, H. Samiilenko, "An innovative approach to determine the sustainable development of regions by harmonization of the economic, social and environmental components," Journal of Management Information and Decision Sciences, 24(S4), 19, 2021. https://doi.org/1532-5806-24-8-340.

[25] S. Tulchynska, O. Popelo, O. Garafonova, I. Yaroshenko, I. Semyhulina, "Modeling the influence of innovative factors on sustainable development of regions in the context of digitalization," Journal of Management Information and Decision Sciences, 24(S5), 18, 2021. https://doi.org/1528-2635-24-8-367.

[26] S. Tulchynska, O. Popelo, O. Garafonova, V. Marhasova, T. Tkachenko, "The impact of modernization on the competitiveness increase of the enterprise and provision of its economic security," Journal of Legal, Ethical and Regulatory Issues, 24(S5), 1-9, 2021.

[27] A. Revko, M. Butko, O. Popelo, "Methodology for Assessing the Influence of Cultural Infrastructure on Regional Development in 
Poland and Ukraine," Comparative Economic Research, Central and Eastern Europe, 23(2), 21-39, 2020. https://doi.org/10.18778/15082008.23.10

[28] C. Skinner, "Digital Human: The Fourth Revolution of Humanity Includes Everyone." UNKNO, 2018.

[29] O. Zybareva, I. Kravchuk, Y. Pushak, L. Verbivska \& O. Makeieva, "Economic and Legal Aspects of the Network Readiness of the Enterprises in Ukraine in the Context of Business Improving," Estudios de economía aplicada, 39(5), 2021. https://doi.org/10.25115/eea.v39i5.4972

[30] J. Y. Huang, J. C. P. Shieh \& Y.-C. Kao, "Starting points for a new researcher in behavioral finance," International Journal of Managerial Finance, 12 (1), 92-103, 2015. https://doi.org/10.1108/IJMF-05-2015-0111

[31] D. Jureviciene \& O. Ivanova, "Behavioral Finance: Theory and Survey," Science - Future of Lithuania, 5(1), 53-58, 2013. https://doi.org/10.3846/mla.2013.08

[32] I. Shkolnyk, V. Chernadchuk \& V. Sukhonos, "The notion and content of financial system in the context of financial law of Ukraine," Problems and Perspectives in Management, 15(2-1), 234-245, 2017. https://doi.org/10.21511/ppm.15(2-1).2017.07

[33] V. Ricciardi \& H. K. Simon, "What is behavioral finance?," Business, Education and Technology Journal, 2(2), 1-9, 2000.

[34] W. DeBondt, W. Forbes, P. Hamalainen \& Y. Gulnur Muradoglu, "What can behavioral finance teach us about finance?," Qualitative Research in Financial Markets, 2(1), 29-36, 2010.

[35] A. Tversky \& D. Kahneman, "The Framing of Decisions and the Psychology of Choice," Science, 211(4481), 453-458, 1981. https://doi.org/10.1126/science.7455683

[36] V. Vovk, A. Denysova, K. Rudoi \& T. Kyrychenko, "Management and legal aspects of the symbiosis of banking institutions and Fintech companies in the credit services market in the context of digitization," Estudios de economía aplicada, 39(7), 2021. https://doi.org/10.25115/eea.v39i7.5013

[37] D. Kahmeman \& A. Tversky, "On the Psychology of Prediction," Psychological Review, 80(4), 237-251, 1973. https://doi.org/10.1037/h0034747

[38] D. Kahneman. "Maps of Bounded Rationality: Psychology of Behavioral Economics," The Americal Economic Review, 93(5), 1449-1475,
2003.

URL:

https://www.jstor.org/stable/3132137

[39] D. Kahneman, "Thinking, fact and slow." NY: Farrar, Straus and Giroux, 2011.

[40] G. Muradoglu, N. Harvey, "Behavioral finance: the role of psychological factors in financial decisions," Review of Behavioral Finance, 4(2), 68-80, 2008. https://doi.org/10.1108/19405971211284862

[41] M. Sadeghnia, A. H. Hooshmand \& Habibniko, "Behavioral Finance and Neuro Finance and Re-search Conducted in this Area," Interdisciplinary Journal of Contemporary Research in Business, 4(12), 793-801, 2013. URL: $\quad$ https://journalarchieves31.webs.com/793-801.pdf

[42] K. C. Tseng, "Behavioural Finance, Bounded Rationality, Neuro Finance and Traditional Finance," Investment Management and Financial Investments, 3(4), 7-18, 2006.

[43] D. Duxbury, "Behavioral finance: insights from experiments I: theory and financial markets," Review of Behavioral Finance, 7(1), 78-96, 2015.

[44] R. H. Thaler, "The End of Behavioral Finance," Financial Analysts Journal, 55(6), 12-17, 1999. https://doi.org/10.2469/faj.v55.n6.2310

[45] R. H. Thaler, "Misbehaving. The making of Behavioral Economics." NY, London: WW Norton \& Company, 2015.

[46] E. Dinga, N. Pop, M. Dimitriu \& C. Milea, "Modeling financial behavior of population conceptual assignations," Romanian Journal of Economic Forecasting, 3, 239-254, 2011. URL:

http://www.ipe.ro/rjef/rjef3_11/rjef3_2011p239 -254.pdf

[47] D. Vaganov, E. Sheina \& K. Bochenina, "A comparative study of social data similarity measures related to financial behavior," Procedia Computer Science, 136, 274-283, 2018. https://doi.org/10.1016/j.procs.2018.08.270

[48] V. Vovk, Y. Zhezherun, O. Bilovodska, V. Babenko \& A. Biriukova, "Financial monitoring in the bank as a market instrument in the conditions of innovative development and digitalization of economy: Management and legal aspects of the risk-based approach," International Journal of Industrial Engineering and Production Research, 31(4), 559-570, 2020. https://doi.org/10.22068/ijiepr.31.4.559

[49] S. Lodhi, "Factors Influemcing Individual Investor Behavior An Empirical Study of City Karachi," Journal of Business and 
Management, 16(2): III, 68-76, 2014. https://doi.org/10.9790/487X-16236876

[50] A. Sarwar \& G. Afaf, "A comparison between psychological and economic factors affecting individual investor's decision-making behavior," Cogent Business \& Management, 3 , 1232907 , 2016. http://dx.doi.org/10.1080/23311975.2016.1232 907

[51] C. Strömbäck, K. Skagerlund, D. Västfjäll \& G. Tinghög, "Subjective self-control but not objective measures of executive functions predicts financial behavior and well-being," Journal of Behavioral and Experimental Finance, 27, 100339, 2020. https://doi.org/10.1016/j.jbef.2020.100339

[52] R. A. Nagy \& R. W. Obenberger, "Factors Influencing Individual Investors Behavior," Financial Analysts Journal, 50(4), 63-68, 1994. https://doi.org/10.2469/faj.v50.n4.63

[53] C. Orden-Cruz \& S. Díaz-Iglesias. Bibliometric analysis on investor protection. Revista de Estudios Empresariales. Segunda época, (1), 137-154, 2020. https://doi.org/10.17561//ree.v2020n1.9

[54] D. Jureviciene \& K. Jermakova, "The Impact of Individuals' Financial Behavior on Investment Decisions," Electronic International Interdisciplinary Conference, 242-250, 2012. URL: https://ojs.mruni.eu/ojs/business-systems-andeconomics/article/view/275/301

[55] B. O’Neill \& J. J. Xiao, "Financial behaviors before and after the financial crisis: Evidence from an online survey," Journal of Financial Counseling and Planning, 23(1), 33-46, 2012. URL:

https://my.afcpe.org/system/journals/v23_j3.pd $\mathrm{f}$

[56] W. F. V. Raaij, "Consumer Financial Behavior," Foundations and Trends $(R)$ in Marketing, 7(4), 231-351, 2014. http://dx.doi.org/10.1561/1700000039

[57] B. C. Madrian, H. E. Hershfield, A. B. Sussman, S. Bhargava, J. Burke, S. A. Huettel \& S. B. Shu, "Behaviorally informed policies for household financial decision making," Behavioral Science \& Policy, 3(1), 27-40, 2017.

URL:

https://static1.squarespace.com/static/5704141c 746fb969109c9a6b/t/5997491fbe42d6618fc46a 2a/1503086915785/Madrian+et+al_BSP+2017. pdf

[58] C. Strömbäck, L. Thérèse, K. Skagerlund, D. Västfjäll \& G. Tinghög, "Does self-control predict financial behavior and financial wellbeing?" Journal of Behavioral and Experimental Finance, 14, 30-38, 2017. https://doi.org/10.1016/j.jbef.2017.04.002

[59] N. Lajuni, I. Bujang, A. A. Karia \& Y. Yacob, "Religiosity, financial knowledge, and financial behavior influence on personal financial distress among millennial generation," Jurnal Manajemen Dan Kewirausahaan, 20(2), 92-98, 2018. https://doi.org/10.9744/jmk.20.2.92-98

[60] F. A. da Silva, M. G. Filho, L. M. M. das Graças, J. M. Tomazela, R. I. de Oliveira, E. R. dos Santos, F. C. de Campos, "Analysis of financial behavior of young people between 20 and 30 years," International Refereed Journal of Engineering and Science, 3(12), 55-64, 2014. URL: http://www.irjes.com/Papers/vol3issue12/Version\%201/I3125564.pdf.

[61] S. Marcellia, "Financial Behavior and Problems Among College Student in Indonesia: the Role of Financial Knowledge," International Journal of Engineering \& Technology, 7, 133137, $2018 . \quad$ URL: https://www.sciencepubco.com/index.php/ijet/a rticle/view/17531

[62] M. V. Deventer, "African Generation Y students' personal finance behavior and knowledge," Investment management and Financial Innovations, 17(4), 136-144, 2020. http://dx.doi.org/10.21511/imfi.17(4).2020.13

[63] M. A. M. A. Daqar, D. Arqawi, S. M. A. Karsh, "Fintech in the eyes of Millennials and Generation Z (The financial behavior and Fintech perception)," Banks and Bank Systems, 15(3), 20-28, 2020. http://dx.doi.org/10.21511/bbs.15(3).2020.03

[64] B. K. Hasibuan, Y. M. Lubis \& H. R. Walad Altsani, "Financial Literacy and Financial Behavior as a Measure of Financial Satisfaction," Advances in Economics, Business and Management Research, 46, 503-507, 2017. https://doi.org/10.2991/ebic-17.2018.79

[65] P. R. Andarsari \& M. N. Ningtyas, "The Role of Financial Literacy on Financial Behavior," Journal of Accounting and Business Education, 4(1), 24-33, 2019. http://dx.doi.org/10.26675/jabe.v4i1.8524

[66] K. Rai, S. Dua \& M. Yadav, "Association of Financial Attitude, Financial Behavior and Financial Knowledge Toward Financial Literacy: A Structural Equation Modeling Approach," FIIB Business Review, 8(1), 51-60, 2019. https://doi.org/10.1177/2319714519826651 
[67] A. Z. Arifin, "The Influence of Financial Knowledge, Control and Income on Individual Financial Behavior," European Research Studies Journal, XX (3A), 635-348, 2017.

[68] R. Komara, A. Widyastuti \& Layyinaturrobaniyah, "Does Financial Literacy Impact Financial Decision Making Among The Government Employee," In Proceedings of the Journal of Contemporary Accounting and Economics Symposium 2018 on Special Session for Indonesian Study (JCAE 2018) Contemporary Accounting Studies in Indonesia, 174-184, $2018 . \quad$ URL: https://www.scitepress.org/Papers/2018/70188/ 70188.pdf

[69] V. R. Sudindra, "Financial Behavior and Decision-Making," International Journal of Creative Research Thoughts IJCRT, 6(1), 1426-1435, 2018. URL: https://www.ijcrt.org/papers/IJCRT1802182.pd f

[70] S. Zulaihat \& U. Widyastuti, "Determinants of consumer financial behavior: Evidence from Households in Indonesia," Journal of Accounting, 6(7), 1193-1198, 2020. https://doi.org/10.5267/j.ac.2020.9.008

[71] D. Jurevicienè \& E. Gausienè, "Peculiarities of individuals' financial behavior," Business: Theory and Practice, 11(3), 222-237, 2010. https://doi.org/10.3846/btp.2010.25

[72] J. J. Xiao \& N. Porto, "Present bias and financial behavior," Financial Planning Review, 2(2), e1048, 2019. https://doi.org/10.1002/cfp2.1048

[73] S. Ismail, F. A. Faique, M. H. Bakri \& Z. M. Zain, "The Relationship between Financial Attitude and Financial Goal Towards Financial Behavior: An Empirical Investigation," The Social Sciences, 12(1), 43-47, 2017. URL: http://docsdrive.com/pdfs/medwelljournals/ssci ence/2017/43-47.pdf

[74] J. Paule-Vianez, R. Gómez-Martínez, C. PradoRomán, "A bibliometric analysis of behavioral finance with mapping analysis tools," European Research on Management and Business Economics, 26(2), 71-77, 2020. https://doi.org/10.1016/j.iedeen.2020.01.001

[75] B. Fakhry, "A Literature Review of Behavioral Finance," Journal of Economics Library, 3(3), 458-465, 2016. http://dx.doi.org/10.1453/jel.v3i3.929

[76] B. A. Joo \& K. Durri, "Comprehensive review of literature on behavioral finance," Indian Journal of Commerce \& Management Studies, VI(2), 11-19, $2015 . \quad$ URL: http://scholarshub.net/index.php/ijcms/article/vi ew/139/133

[77] A. Pimenta \& R. Famá, "Behavioral finance: a bibliometric mapping of academic publications in USA since 1993," 2014. URL: https://papers.ssrn.com/sol3/papers.cfm?abstrac $\mathrm{t}$ id $=2406763$

[78] O. Pasko, I. Balla, I. Levytska, N. Semenyshena, "Accountability on Sustainability in Central and Eastern Europe: An Empirical Assessment of SustainabilityRelated Assurance", Comparative Economic Research. Central and Eastern Europe, 24(3), pp. 27-52, 2021. https://doi.org/10.18778/1508-2008.24.20

[79] K. Shaposhnykov, A. Abramova, A. Zhavoronok, P. Liutikov, I. Skvirskyi \& O. Lukashev, "Ecosystem of VAT Administration in E-Commerce: Case of the Eastern Europe Countries", Estudios de economía aplicada, 39(5), 2021. http://dx.doi.org/10.25115/eea.v39i5.4909

[80] M. Dubyna, N. Kholiavko, A. Zhavoronok, Y. Safonov, D. Krylov, Y. Tochylina, "The ICT Sector in Economic Development of the Countries of Eastern Europe: a Comparative Analysis," WSEAS Transactions on Business and Economics, vol. 19, pp. 169-185, 2022

[81] A. Viknianska, D. Kharynovych-Yavorska, M. Sahaidak, A. Zhavoronok, \& V. Filippov, "Methodological approach to economic analysis and control of enterprises under conditions of economic systems transformation", Naukovyi Visnyk Natsionalnoho Hirnychoho Universytetu, 4, pp. 150-157, 2021. https://doi.org/10.33271/nvngu/2021-4/150

[82] R. Biloskurskyy, A. Verstiak, I. Vinnychuk, "Sectoral Analysis of Environmental Economics: The View from Ukraine", Scientific Annals of Economics and Business, 66(3), pp. 321-334, 2019.

[83] O. Mykytiuk, Z. Varnalii, D. Nikytenko, S. Gedek, L. Pashnyuk, "Investment determinants of economic growth: World experience and Ukraine", Intellectual Economicsthis, 2020, 14(2), pp. 106-123, 2020.

[84] V. Lytvynenko, D. Nikytenko, M. Voronenko, N. Savina, O. Naumov, "Assessing the Possibility of a Country's Economic Growth Using Dynamic Bayesian Network Models", International Scientific and Technical Conference on Computer Sciences and Information Technologies, 1, 9321995, pp. 3639, 2020. 
[85] O. Pasko, L. Zhang, K. Bezverkhyi, D. Nikytenko, L. Khromushyna, "Does external assurance on CSR reporting contribute to its higher quality? Empirical evidence from China", Investment Management and Financial Innovations, 18(4), pp. 309-325, 2021.

[86] A. Kornyliuk, Y. Polishchuk, I. Lopashchuk, A. Pinchuk, "SMEs debt financing in the EU: on the eve of the coronacrisis," Banks and Bank Systems, 15(3), 81-94, 2020. https://doi.org/10.21511/bbs.15(3).2020.08

[87] O. Dyba, Y. Polishchuk, A. Ivashchenko, "Smart-contracts via blockchain as the innovation tool for smes development," Ikonomicheski Izsledvania, 28(6), 39-53, 2019.

[88] B. Danylyshyn, M. Dubyna, M. Zabashtanskyi, N. Ostrovska, K. Blishchuk, I. Kozak, "Innovative Instruments of Monetary and Fiscal Policy," Universal Journal of Accounting and Finance, 9(6), 1213-1221, 2021. https://doi.org/10.13189/ujaf.2021.090601

[89] N. Ostrovska, N. Hrapko, "Condition and dynamics of lending analysis in Ukraine (20112013)," Economic Annals-XXI, 9-10(2), 15-18, 2014.

[90] A. Ivashchenko, I. Britchenko, M. Dyba, Ye. Polishchuk, Yu. Sybirianska, Yu. Vasylyshen, "Fintech platforms in SME's financing: EU experience and ways of their application in Ukraine," Investment Management and Financial Innovations, 15(3), 83-96, 2018. https://doi.org/10.21511/imfi.15(3).2018.07

[91] V. Margasova, Y. Kovalenko, O. Bereslavska, O. Muravskyi, M. Fedyshyn, O. Kolesnik, "Instruments of monetary-and-credit policy in terms of economic instability," International Journal of Management, Volume 11(5), 43-53, 2020.

https://doi.org/10.34218/IJM.11.5.2020.005

[92] I. Tkachuk, "Asset operations of Ukrainian banks on the current stage of banking system development," Banks and Bank Systems, 12(11), 119-127, 2017. https://doi.org/10.21511/bbs.12(1-1).2017.04

[93] O. Pasko, F. Chen, A. Oriekhova, A. Brychko, I. Shalyhina, "Mapping the Literature on Sustainability Reporting: A Bibliometric Analysis Grounded in Scopus and Web of Science Core Collection," European Journal of Sustainable Development, 10, 1, 303-322, 2021.

[94] E. Baraibar-Diez, M. Luna, M. D. Odriozola, \& I. Llorente, "Mapping Social Impact: A Bibliometric Analysis," Sustainability, 12(22),
9389, 2020. https://doi.org/10.3390/su12229389

[95] M. Rodrigues, \& L. Mendes, "Mapping of the literature on social responsibility in the mining industry: A systematic literature review," Journal of Cleaner Production, 181, 88-101, 2018

\section{Creative Commons Attribution}

\section{License 4.0 (Attribution 4.0 \\ International , CC BY 4.0)}

This article is published under the terms of the Creative Commons Attribution License 4.0 https://creativecommons.org/licenses/by/4.0/deed.en US 